\title{
TUTKIMUSKOHTEENA LÄHEINEN IHMINEN
}

\section{Refleksiivisen ja dialogisen tutkimusotteen mahdollisuudet ja rajoitteet etnografisessa tutkimuksessa ${ }^{1}$}

\author{
Eerika Koskinen-Koivisto
}

Moni perinteentutkija, kansatieteilijä tai folkloristi haastattelee jossain vaiheessa itselleen läheistä inmistä, sukulaista tai ystävää. Jokainen tutkimusasetelma on aina erityinen, ja tässä artikkelissa asetelmaa määrittää erityisesti tutkijan aiempi, jatkuva ja muuttuva suhde tutkittavaan. Palaan tässä artikkelissa tarkastelemaan omaa väitöskirjaprosessiani ja lähestyn sitä niin refleksiivisestä kuin dialogisestakin viitekehyksestä käsin.

Olen tutkinut väitöskirjassani (Koskinen-Koivisto 2013) isoäitini Elsa Koskisen (s. 1927) kertomuksia elämästään ja paikastaan maailmassa. Olen ollut kiinnostunut erityisesti hänen kokemuksistaan sukupuolesta, luokasta ja työstä sekä näillä elämänalueilla tapahtuneista muutoksista. Väitöskirjassani pyrin analysoimaan Elsan kertomuksia paitsi suhteessa hänen elämänhistoriaansa ja kokemustensa kirjoon, myös kulttuurisen kontekstiin, jonka pitkä aikajänne ulottuu menneisyydestä nykypäivään.

Lähtökohtanani oli, että neuvottelu yksilön kokemusten ja kulttuuristen normien ja ideaalien välillä rakentuu ylisukupolvisessa dialogissa, jonka toinen osapuoli itse olen. Tutkimuskohteen läheisyyden ja oman osallisuuteni vuoksi tavoitteeni oli ulottaa refleksiivisyys tutkimusprosessin kaikkiin vaiheisiin niin, että ottaisin huomioon läheisen suhteemme ja sisäpiiriläisyyteni osana tiedontuotannon prosessia. Jälkikäteen tarkasteltuna vaikuttaa kuitenkin siltä, että tutkimusasetelmastani ja tavoitteestani

\footnotetext{
1 Kiitän Eloren toimittajia ja anonyymeja lausunnonantajia sekä kollegaani Pilvi Hämeenahoa rakentavista kommenteista tekstiini.
}

Elore (ISSN 1456-3010), vol. 21 - 2/2014. Julkaisija: Suomen Kansantietouden Tutkijain Seura ry. [http://www.elore.fi/arkisto/2_14/koskinen-koivisto.pdf] 
huolimatta onnistuin monin paikoin häivyttämään tai piilottamaan itseni, omat tavoitteeni ja osuuteni tutkimuksessani esittämiini tulkintoihin.

Haastattelututkimuksen perustaminen dialogiselle metodologialle, jossa tiedon nähdään rakentuvan prosessinomaisena ja intersubjektiivisena tutkijan ja tutkittavan välisenä vuorovaikutuksena (ks. esim. Crapanzano 1990; Mannheim \& Tedlock 1995, Vasenkari 1996; Vasenkari \& Pekkala 2000), voisi ajatella olevan luontevaa ja ongelmatonta erityisesti yhden haastateltavan ja tutkittavan kohdalla. Dialogisuuden haasteena on kuitenkin sen laajuus ja abstraktius: yhdenkään kohtaamisen kaikkia nyansseja ja kommunikaation moniulotteisuutta sekä taustalla vaikuttavia konteksteja ei voi kuvata tyhjentävästi (Mannheim \& Tedlock 1995, 10). Lisäksi dialogilla ja dialogisuudella voidaan katsoa olevan ainakin kolme ulottuvuutta, ontologinen, funktionaalinen ja eettinen / poliittinen, jotka vaikuttavat tutkimusprosessiin (ks. Mannheim \& Tedlock 1995, 4). Etnografinen tutkimus ammentaa dialogisesta ontologiasta: dialogisuus on läsnä kaikessa ihmisten välisessä toiminnassa, sillä toisen ihmisen ajatuksiin pääse käsiksi vain ajatusten jakamisen eli kommunikaation kautta. Voidaankin siis ajatella, että kaikki vuorovaikutukseen perustuvat tutkimusaineistot ovat luonteeltaan dialogisia (Sawin 2004, 9-10). Myös elämänkertomuksen eli kertojan muotoileman kertomuksen itsestään voi katsoa muodostuvan aina suhteessa toiseen ja / tai toisiin (esim. Aro 1996, 48; Sawin 2004, 2; Collins \& Gallinat 2010, 14). Kertoessaan elämästään yksilö käy myös dialogia oman itsensä ja eri-aikaisten minuuksiensa kanssa (Bahktin 1981). Tällainen dialogi on myös funktionaalista eli toiminnallista ja toimintaan tähtäävää, ja tässä tapauksessa sen tarkoitukseksi voi nähdä muun muassa menneiden kokemusten (ja samalla oman kertomuksen, minuuden ja identiteetin) arvioimisen sekä kokemusten ja kertomusten jakamisen. Dialogisuuden eettinen ja poliittinen ulottuvuus puolestaan liittyy ennen kaikkea tutkijan valintoihin ja valtaan, erilaisten äänien esille tuomiseen ja esittämisen politiikkaan. (Mannheim \& Tedlock 1995, 4-5.)

Vaikka haastattelututkimuksen intersubjektiivisuus ja dialogisuus sekä dialogisuuden eri ulottuvuudet ovatkin olleet esillä elämäkerrallisessa tutkimuksessa (esim. Aro 1996, Ukkonen 2000; Löyttyniemi 2004), ei dialogisuutta menetelmänä ja osana haastatteluaineiston tulkintaa ole juurikaan ekplisiittisesti pohdittu (ks. myös Sykäri 2012, 81; poikkeuksena tästä Sawin 2004). Miten dialoginen metodologia ohjaa etnografista tutkimusprosessia? Miten elämäkerrallista aineistoa voisi analysoidaan dialogisesta näkökulmasta? Arvioin tulevassa refleksiivisyyden ja dialogisen metodologian toteutumista, mahdollisuuksia ja rajoitteita käyttäen esimerkkinä omaa väitöstutkimustani. Huomioidakseni dialogisuuden eri ulottuvuudet käyn läpi tutkimusprosessin vaihe vaiheelta ja pohdin, miten 
ja millaiseksi tuottamani tieto rakentui, ja miten refleksiivisyys ja dialogisuus ohjasivat tutkimustani ja toteutuivat sen eri vaiheissa: aiheen valinnassa ja kysymysten muotoutumisessa, aineistonkeruun ja haastattelun konteksteissa, tutkimuseettisissä valinnoissa sekä analyysin ja tulkintojen prosessissa, joka kulminoituu tutkimustekstin kirjoittamiseen. Samalla tulen pohtineeksi myös läheisen suhteen ja sukulaisuuden vaikutusta dialogin syntymiseen ja luonteeseen sekä tehtyihin tulkintoihin. Mitä tästä tutkijan kaksoisroolista oikeastaan seuraa, ja mahdollistaako vai estääkö tutkimuskohteen läheisyys dialogisen metodologian toteutumisen tutkimuksen eri vaiheissa?

\section{DIALOGISUUDEN JA REFLEKSIIVISYYDEN YHTEENKIETOUTUMINEN}

Dialogista tuli etnografisen tutkimuksen metafora ja ihanne niin sanotun refleksiivisen käänteen aikana, jolloin vieraiden kulttuurien ja toisten tutkimisen oikeutus kyseenalaistettiin ja tutkijat ryhtyivät etsimään uusia tapoja kirjoittaa etnografiaa (Marcus \& Fischer 1986, 68; Tedlock \& Mannheim 1995, 2-3; ks. myös Sykäri 2012). Antropologit, jotka tunnustivat tiedon osittaisuuden ja sidoksen tutkijan edustamaan länsimaiseen näkökulmaan, alkoivat pohtia omaa osuuttaan tutkimusprosessissa ja kirjoittaa itsensä mukaan tutkimukseen arvioimalla omaa suhdettaan tutkimuskohteeseen, tutkimisen tapoihin ja tuotettuun tietoon. Dialogisen tutkimusotteen tavoitteena oli tekstin ja tulkintojen moniäänisyys. (Mannheim \& Tedlock 1995, 5; Vasenkari \& Pekkala 2000.) Tätä refleksiivistä tutkimusotetta ja prosessia alettiin myöhemmin kutsua paikantumiseksi.

Käsite paikantunut tieto (situated knowledge) on peräisin naistutkimuksesta, jonka piirissä tiedon osittaisuudesta ja subjektiviisuudesta on tullut tutkimuksen lähtökohta ja objektiivisuuden edellytys: tutkijan on eksplikoitava, mistä näkökulmasta hän tutkimusta tekee (Liljeström 2004; Ojanen 2008). Paikantuneisuus merkitsee siis tutkijan tietoista asemoitumista tiettyihin teoriaperinteisiin ja metodologiaan, paikantumisen julkilausumista tutkimustekstissä sekä tutkijan oman taustan reflektointia niiden asioiden osalta, joiden olettaa olevan työssään olennaisia (ks. Liljeström 2004, 11-13; Ojanen 2008). Etnologi Outi Fingerroosin (2003) mukaan paikantaminen voidaan nähdä lähes synonyyminä refleksiivisyydelle. Paikantamisella hän viittaa ensisijaisesti tutkimuksen tekemisen prosessiin ja sen subjektisidonnaisuuden hahmottamiseen ja reflektoinnilla tämän asetelman julkituontiin. Käyttämällä molempia käsitteitä refleksiivisestä paikantamisesta Fingerroos korostaa tutkijan tekemän paikantamisen merkitystä ja sen näkyväksi tekemistä itse tutkimustekstissä.

On kuitenkin vaikea määritellä, milloin refleksiivinen paikantuminen on riittävää ja onnistunutta. Omia kokemuksiaan tallityttöihin kohdistuvassa 
tutkimuksessaan hyväksi käyttänyt folkloristi Karoliina Ojanen $(2008,3)$ huomauttaa, ettei refleksiivinen analyysitapa sinällään riitä tieteellisen tiedon kriteeriksi. Tutkija ei voi oikeuttaa tulkintojaan pelkästään vetoamalla omaan yhteiskunnalliseen taustaansa ja muihin häntä paikantaviin tekijöihin, eikä refleksiivinen ote ole vastaus kaikkeen, sillä myös refleksiivisestikin tuotettu tulkinta on sidoksissa tiettyyn aikaan ja paikkaan. Myös Fingerroos (2003) peräänkuuluttaa refleksiivisyyden laajentamista muualle kuin itsereflektion tasolle. Tutkijan tulisi tiedostaa ja kirjoittaa auki myös suhteensa metodologiaan eli menetelmiin, teorioihin ja käsitteisiin, epistemologiaan eli tietoteoriaan, tiedonintressiin ja kulttuurin käsitteeseen sekä tutkimuksen ulkoisiin, poliittisiin ja vallankäyttöön liittyviin sitoumuksiin. Myös eettiset kysymykset voidaan nähdä osana refleksiivisen paikantumisen laajaa määritelmää. Refleksiivisyys tulisikin nähdä vuorovaikutuksellisena prosessina. Se viittaa tutkijan ja tutkittavan väliseen maailmaan, joka on tutkimuksen varsinainen kohde ja se, mitä tutkimus voi saavuttaa. Ojasta lainatakseni "tutkimus kertoo tutkijan suhteesta tutkittavaan ilmiöön, ilmiöstä sellaisena kuin se tutkijan kanssa oli" (Ojanen 2008, 3).

Refleksiivisyydessä on siis yksinkertaistettuna kyse suhteesta tutkimuskohteeseen. Sen lisäksi, että tutkija erittelee, millaisissa asemissa dialogin osapuolet ovat, hänen tulisi kiinnittää huomiota myös siihen, mitä hänen ja tutkittavan välissä tapahtuu, millaiseksi heidän välisensä vuorovaikutus ja ymmärrys kehittyvät, ja mitä siitä seuraa. Omassa tutkimusprosessissani vuorovaikutuksen etenemisen refleksiivinen analyysi ja erityisesti sitä seuraavien tekojen ja ymmärryksen huomioiminen jäivät monilta osin vajaiksi, mikä johti siihen, että tein tulkintoja enimmäkseen Elsan kertomuksista, enkä niinkään välillämme käydystä dialogista. Osittain tämä johtui analyysimallista, joka keskittyi dialogin sijaan kertomusten analyysiin. Erottelin Elsan elämänkerrontaan sisältyvät kertomukset eli mikronarratiivit $^{2}$ muusta aineistosta, jonka jätin vähemmälle huomiolle, ja analysoin käsittelyluvuissani ennen kaikkea mikronarratiivien keskinäisiä suhteita. Kiinnitin kyllä huomiota haastattelutilannekontekstiin ja tarkkailin omia puheenvuorojani. En kuitenkaan tehnyt systemaattista puheenvuorojen analyysia (ks. esim. Aro 1996) tai soveltanut muita puheen etnografiaan (ethnography of speech) liittyviä lähtökohtia kerronnan analyysissä (esim. Klein 2006), jotka olisivat voineet olla hyödyllisiä vuorovaikutuksemme ja omien roolieni ja niiden vaikutusten purkamiselle. En myöskään juurikaan pohtinut, mitä kertomusten jakamisesta seuraa,

\footnotetext{
${ }^{2}$ Vaikka mikronarratiivin voi nähdä lähes synonyymina kertomuksen kanssa, korostaa etuliite mikro kerrotun tapahtumakulun tai kokemuksen yhteyttä elämänkertomuksen kokonaisuuteen, joka koostuu keskenään erilaisista ja joskus ristiriitaisistakin kertomuksista (Koskinen-Koivisto 2013). Käsite mikronarratiivi kuvaa siis kertomusten suhdetta laajempaan merkityksenannon kontekstiin, tässä tapauksessa elämänkerrontaan.
} 
miten tulkinnat vaikuttavat välillämme vallitsevaan suhteeseen ja millaiseen ymmärrykseen ne johtivat. Pyrin siis seuraavaksi korjaamaan tätä puutetta erittelemällä tutkimusprosessiin liittyviä valintojani ja niiden seurauksia tutkimusprosessin eri vaiheissa sekä arvioimaan omaa rooliani tiedontuotannon prosessissa.

\section{TUTKIMUSKOHTEEN VALINTA: KOMMUNIKAATION NÄENNÄISESTÄ HELP- POUDESTA EROJEN MERKITYKSELLISYYTEEN}

Etnografisen tutkimuksen, joka kohdistuu tutkijalle tuttuun ympäristöön, "kotikenttään" ja omaan kulttuuriin, on katsottu yleistyneen viime vuosikymmeninä globalisoituneessa, verkottuneessa ja pirstaloituvassa maailmassa (esim. Davies 2002; Collins \& Gallinat 2010). Erityinen lukunsa kotikentälle sijoittuvissa etnografioissa on omaan sukuun ja lähipiiriin liittyvä tutkimus, jonka suhteen folkloristien voidaan katsoa olevan jonkinlaisia edelläkävijöitä. Useat folkloristit ovat nähneet sisäpiiriläisyydessä ja haastateltavien tuttuudessa monia etuja. Susan Sheiberg (1990) on kertonut suosittelevansa opiskelijoita tutkimaan oman perheensä kertomuksia, sillä perheenjäsenten kesken vallitseva luottamuksen ilmapiiri helpottaa kenttätyöprosessia ja tallentamista. William Wilson (1991) puolestaan on korostanut omaan sukuun liittyvien kertomusten lisäävän ymmärrystä paitsi omasta taustasta myös kertomuksiin sisältyvästä emotionaalisesta latauksesta ja merkityksestä ylipäänsä. Molemmat näkökulmat ovat varteenotettavia ja puoltavat sukulais(t)en valintaa tutkimuskohteeksi. Ne ohjasivat myös minua tutkimusprosessini alussa: aloin tallentaa isoäitini kerrontaa elämästään ruukkiyhteisössä erästä folkloristiikan opintojen kurssia varten ajatuksena tavoittaa teollisen yhteisön suullista perinnettä. Jo ensimmäisessä haastattelussa isoäitini kertoi paitsi ruukkiyhteisön suullista perinnettä ja toisilta kuulemiaan kertomuksia myös omia henkilökohtaisia kokemuksiaan elämästä ruukkiyhteisössä. Jatkoin haastatteluja erilaisista nimenomaan hänen elämäänsä liittyvistä teemoista ja elämänvaiheista. Uskoisin, että isoäitini olisi kertonut elämästään ja kokemuksistaan minulle muutenkin, mutta kenties satunnaisemmin ja rajatummin.

Edellä mainitut syyt - vaivatta kertynyt aineisto ja intuitiivinen ymmärrys kertomusten merkityksestä - eivät kuitenkaan yksin riittäneet perusteiksi jatkaa tutkimusta isoäitini kertomuksista väitöskirjaksi asti. Jouduin pohtimaan tutkimusaiheen rajausta ja näkökulmaa paitsi kirjoittaessani tutkimussuunnitelmaa myös selittäessäni isoäidilleni, miksi halusin jatkaa eteenpäin hänen elämänkerrontansa analyysiä ja miksi se olisi tärkeää. Kerroin, että halusin tutkia sekä tehdastyötä tehneitä naisia että heidän arkeaan. Ajatukseni oli etsiä lisää tutkittavia tai aiheeseen liittyvää 
arkistoaineistoa. Päädyin kuitenkin tarkastelemaan pelkästään Elsaa ja valmiina olevaa aineistoa, sillä sitä oli runsaasti. Tiesin haastatteluaineiston sisältävän kiinnostavia kertomuksia palkkatyön merkityksestä sekä työläisyyteen ja naisen asemaan liittyvistä, tavallisista mutta arkaluontoisista ja ristiriitaisista ilmiöistä kuten sosiaalisesta noususta, joka kosketti Elsan ja muun perheeni elämää. Ajattelin henkilökohtaisten kertomusten sisältävän olennaista tietoa lähes jokaista suomalaista koskettaneista yhteiskunnallisista muutoksista. Kertomuksissa, jotka rakentuvat sekä ajallisen että kausaalisen kerronnallisen jännitteen varaan (ks. esim. Siikala 1984, 22-23, 28), on nimittäin oltava jotain kerrottavaa, joka suhteutuu jaettuihin kulttuurisiin arvoihin ja normeihin (ks. Arvidsson 1999, 26; Marander-Eklund 2011, 148). Niiden avulla voidaan myös hallita ja ymmärtää aikaa ja muutosta, mikä tekee niistä kiinnostavia tutkimukselle (Hyvärinen \& Löyttyniemi 2005, 189-191).

Kahteentoista tekemääni haastatteluun sisältyi lähes 300 mikronarratiivia lukuisista eri teemoista: Elsa ei kuitenkaan vastannut kaikkiin kysymyksiini eikä kertonut minulle tietyistä vaiheista elämässään. Elsa ei esimerkiksi kertonut minulle juurikaan arjestaan kotiäitinä, eikä itsestään vanhempana tai isovanhempana. Hän ei myöskään kertonut suhteestaan omaan puolisoonsa eikä lapsiinsa. Tämä lienee seurausta siitä, että nämä elämän osa-alueet, jotka määrittivät myös keskinäistä sukulaissuhdettamme, olivat liian lähellä meitä molempia ja siten oletetusti minulle ennestään tuttuja ja Elsalle liian itsestään selviä kerronnan ja keskustelun kohteita. On myös mahdollista, että Elsa oletti, etten minä nuorena (akateemisena) opiskelijana ollut erityisen kiinnostunut näistä aihepiireistä vaan jostain muusta, jostain "tärkeämmästä" ja virallisesta, kuten hänen työurastaan ja laajemmista yhteiskunnallisista kysymyksistä. Kysyessäni häneltä arjesta lasten kanssa hän käänsi keskustelun heti työhön:

Eerika (jatkossa EE): Minkäslaista se arki siellä oli sitte lasten kanssa siellä Ruukilla?

Elsa (jatkossa E): No, määhän en ollu sillon töissä. Kun tuota niin, mää olin niinkun, semmonen niinkun kesälomantuuraaja. Että mää, sillon pyyettii mua sitten, kun toiset jää kesälomalle, niin siellä kuitenkin pyöri jotku artikkelit. (H5, s. 15)

Onkin todennäköistä, että hän olisi kertonut niistä jollekin muulle, esimerkiksi minua vanhemmalle ja hänen ikäryhmäänsä lähempänä olevalle henkilölle, joka olisi voinut jakaa hänen kanssaan omia kokemuksiaan tai jolle Elsa olisi halunnut esiintyä nimenomaan vanhempana naisena, äitinä ja isovanhempana. Vertaistensa, esimerkiksi toisten entisten työläisnaisten kanssa Elsa taas olisi ehkä voinut jakaa myös enemmän heikkouden tai riittämättömyyden kokemuksia.

Hain ensimmäisestä haastattelusta alkaen tietoa kokemuksista, joissa korostuisivat niin luokkien kuin sukupolvienkin väliset erot ja niissä 
tapahtuneet muutokset, kuten esimerkiksi naisen asemaan tai sosiaaliseen nousuun liittyvät kysymykset. Monet näistä tulivat esiin ja merkityksellistyivät nimenomaan suhteessa muutoksiin, nykyaikaan ja omien kokemusteni erilaisuuteen. Olettamukseni ja mielipiteeni tulivat esiin haastatteluissa perin asenteellisten kysymysten kautta:
EE: Kertoko naiset mitään juttuja yleensä vai oliko ne miehet jotka kerto?
E: Miehet vaan oli, et emmää, ei naiset ollu.
EE: Vanhat mummot, kertoko ne juttuja? Tarinoita tai?
E: No niillä oli kato semmosia niitä omia ongelmiaan ne tuota kertovat että, ei nykyajan ihiminen sillä lailla pystys elämään ol- lenkaan.

EE: Nii?

E: Kun ne eli. Siis eihän, eihän sen aikuinen mies niinku tehny naiselle, nainen, nainenhan oli vaan niinku...[etsii sanaa]

\section{EE: Palvelija?}

E: Palvelia. Niin. Ettei ne osallistunu naisten töihin.

EE: Niin.

$E$ : Ja tota niin, ja menivät omia teitää.

EE. Niin, niin.

E: Nii että kyllähän näistä tämmösistä puhuttiin, hyvin paljo on niin ku nytte kyllä mää näin, kaikenlaista, mutta sitä ei sillon ymmärtäny mitä se oli, mutta nyt tullee mielee ja kyllä mää sille mun siskolle, jokon monta kertaa puhelimessa niin me toisillemme kerrotaan, että kuvittele sää, että ku ei me sillon ymmärretty näitä asioita. (H1, s. 16.)

Erot Elsan ja minun elämänpiireissä ajoivat siis minut paitsi jatkamaan haastatteluja myös pohtimaan tarkemmin luokkaan, sukupuoleen ja työhön liittyviä muutoksia. En kuitenkaan osannut kirjoittaa auki tätä tutkimuskohteen valintaa, enkä yhdistää sitä dialogiseen lähestymistapaan, josta käsin kokemusten erilaisuus ja aineiston edustama sukupolvien välinen dialogi on riittävä perustelu tutkimuskohteen valinnalle. Etnografisen - ja laadullisen tutkimuksen ylipäänsä - tarkoituksenahan on rakentaa siltoja erilaisista lähtökohdista hahmottuvien todellisuuksien välille (ks. Davies 2002, 6; myös Alver 1990). Toisistaan kaukana olevat kokemusmaailmat voivat toimia hedelmällisenä lähtökohtana, jos ne tiedostetaan ja problematisoidaan. Folkloristi Patricia Sawinin (2004) tutkimus amerikkalaisesta Appalakkien alueella asuvasta kansanlaulujen taitajasta Bessie Eldrethistä muotoutui - toisin kuin Sawin alunperin suunnitteli - dialogiseksi etnografiaksi, jonka johtolangaksi nousivat tutkijan ja tutkittavan väliset erot ja niitä peilaava tulkinnan prosessi. Refleksiivinen ja dialoginen ote läpäisevät koko tutkimuksen, jossa Sawin 
pohtii Appalakkien alueen kulttuuria ja kertojan paikantumista suhteessa omaan akateemiseen ja feministiseen taustaansa.

Lähipiirin ja perheenjäsenten kanssa jaettujen kokemusten ja tunteiden sekä niiden erilaisuuden taustalla olevien laajempien kysymysten, kuten arkipäivän historian ja yhteisöjen sosiaalisen dynamiikan ymmärtämiselle on myös löydettävissä hyviä esimerkkejä lähitieteistä. Brittiläisen historioitsijan Carolyn Kay Steedmanin (1994) ja amerikkalaisen sosiologin Mary Patrice Erdmansin (2004) omiin perhetaustoihinsa kohdistuvat tutkimukset avasivat uudenlaisia näkökulmia sukupuoleen, perheen sosiaaliseen asemaan ja luokkaidentiteettiin. Steedmanin henkilökohtainen tutkimus äitinsä menneisyydestä ja omista muistoistaan käsitteli työväenluokkaisen perheen elämään vaikuttaneita sosiaalisia voimia ja olosuhteita sekä niiden aiheuttamia tunteita, mikä lisäsi olennaisesti ymmärrystä luokka-asemasta ja sukupuolten välisistä suhteista toisen maailmansodan jälkeisessä Britanniassa. Erdmans puolestaan kiinnitti tutkimuksellaan huomiota tutkijoiden laiminlyömään valkoiseen työväenluokkaan, jonka naiset jäivät usein hoitamaan kotia mutta pitävät tätä valintaa hyvänä ja elämäänsä ylipäätään onnellisena. Molempien tutkimusten kohdalla tutkimuskentän läheisyys tuotti ainutlaatuista aineistoa ja tietoa, jota perheen ulkopuolinen ei todennäköisesti olisi löytänyt, osannut kysyä tai kyseenalaistaa ja asettaa kontekstiinsa.

Uskoakseni myöskään Elsaa ja hänen kertomuksiaan ei olisi "löydetty" ilman minun kiinnostustani. Nuoruutensa voimisteluharrastusta lukuun ottamatta Elsa ei juuri ottanut osaa järjestötoimintaan. Hän ei ollut poliittisesti aktiivinen, eikä edes osallistunut eläkeläisille suunnattuun toimintaan, vaan eli hyvin hiljaista elämää omassa perhepiirissään. Olin saanut tutustua kertomuksiin hänen elämästään ja työstään keittiön pöydän ääressä ja kuulla kertomuksia henkilökohtaisista ja usein kipeistäkin kokemuksista, jotka muokkasivat merkittävällä tavalla omaa ymmärrystäni 1900-luvun suomalaisesta yhteiskunnasta. Valitessani tutkimuskohdettani en oikeastaan epäillyt, etteikö Elsan kertomuksilla olisi annettavaa etnologiselle ja folkloristiselle tutkimukselle sekä ymmärrykselle suomalaista yhteiskuntaa koskettavista laajemmista ilmiöistä, varsinkin jos onnistuisin kontekstualisoimaan hänen kerrontansa suhteessa suomalaisessa yhteiskunnassa vallinneisiin sosiaalisiin olosuhteisiin ja historiallisiin tapahtumiin. Uskoakseni onnistuin tässä kohtuullisesti. Sitä useammin kuitenkin pohdin, tekisivätkö tulkintani oikeutta kertojalleen ja pystyisinkö perustelemaan tutkimusprosessiin liittyvät valinnat ja tulkintani itselleni ja lukijoille. Nämä epäilyt saivat minut paikoin jopa välttämään kirjoittamasta itseäni ja omia tulkintojani mukaan tutkimustekstiin. En myöskään onnistunut purkamaan haastattelutilanteisiin liittyvää vuorovaikutustamme ja läheisestä suhteestamme aiheutuneita sitoumuksia. 
DIALOGISEN TILAN JA VUOROVAIKUTUKSEN RAKENTUMINEN HAASTATTELUISSA

Folkloristi Venla Sykäri (2012) huomauttaa, ettei dialogi synny itsestään tai ole välttämättä läsnä tutkijan ja tutkittavan ensimmäisessä tapaamisessa tai haastattelukerralla, vaan se syntyy usein vasta molempien osapuolten harjoittaman pohdinnan ja keskusteluyhteyden hakemisen jälkeen. Tutkija ei useinkaan tunne tutkittavaa ympäristöä ja kulttuuria ennen kentälle menoa muutoin kuin tutkimuskirjallisuuden kautta, eikä välttämättä osaa kysyä "oikeita" kysymyksiä. Haasteltava puolestaan kertoo siitä, mitä uskoo tutkijan haluavan kuulla ja usein nimenomaan vakiintuneiden kertomusten muodossa. Toistuvat haastattelut tarjoavat mahdollisuuden ylittää ensikohtaamisen jännitys ja vieraus ja luoda dialoginen tila, jossa molemmat osapuolet, niin kertoja kuin tutkijakin voivat esittää omia ajatuksiaan, mielipiteitään ja tulkintojaan.

Omaa perhettään tai lähipiiriään haastatteleva tutkija ei joudu kohtaamaan täysin vierasta inmistä. Voisikin ajatella, että dialogisuuden tavoittelu olisi helpompaa sisäpiiriläiselle, kuten poronhoitoa tutkinut ja poronhoitajien sukuun lukeutuva kansatieteilijä Helena Ruotsala (1998, 107) esittää. Hänen kokemuksensa kenttätyöstä oman sukunsa ja yhteisönsä piirissä olivat monin tavoin myönteisiä, häntä autettiin mielellään ja hänen tutkimuksensa julkaisemista odotettiin innolla. Toisaalta Ruotsala kuitenkin huomauttaa, että tutulla maaperällä liikkuva tutkija saattaa myös olla tietoisempi tutkijan roolistaan, sillä tilanne poikkeaa tavallisesta vuorovaikutuksesta (Ruotsala 1998, 109; ks. myös Klein 2006).

Oma kokemukseni haastatteluprosessista tukee kuitenkin osin Sykärin havaintoa dialogisen tiedon kehittymisestä pikku hiljaa, toistuvien kohtaamisten myötä. Tämä ei johdu vain haastateltavan jännityksestä ja tavoitteesta vastata "oikein", vaan myös haastattelijan kokemusten karttumisesta, herkistymisestä, tilan antamisesta ja rohkeudesta kysyä ja kyseenalaistaa. Huomasin, etten antanut ensimmäisissä haastatteluissa Elsalle tilaa kertoa vapaasti, vaan täytin keskustelumme kysymyksillä, enkä useinkaan odottanut hänen muotoilevan ajatuksiaan loppuun:

\footnotetext{
EE: Mmm. Mites ne muuten juttuja kerto? Varmaan sitte ku vanhemmaks tulit niin muistat vielä paremmin.

E: Niin. Niin kyllä niitä kaikkia no aina miehet-

EE: [keskeyttää] Vitsiä tietenki ja?

$\mathrm{E}$ : Joo, kyllä ne on niin hauskoja että sitte kun me istuttiin... (H1, s. 3.)
}

Tällainen liiankin innokas ja hitusen epäkohteliaskin käytös oli mahdollista, koska haastateltavana oli minulle entuudestaan tuttu inminen. Kysymykset myös korostivat rooliani tutkijana ja asiantuntijana, joka oli uusi 
rooli suhteessa aiempaan rooliini Elsan tarinoiden kuulijana. Olen myös huomannut, että toisinaan esiinnyin jonkinlaisena Inhantehtaiden historian asiantuntijana ja esittelin Elsalle tietämystäni hänen taustayhteisöstään ja työpaikastaan sekä ylipäätään paikallishistoriasta.

Huomasin haastatteluprosessin kuluessa, että jotkut aiheet, kuten esimerkiksi puhuminen seksuaalisesta häirinnästä, joka liittyi työskentelyyn nuorena naisena miesvaltaisessa yhteisössä, vaativat paitsi kysymyksiä ja maanittelua, myös tilaa ja hiljaisuutta. Neljännessä haastattelussa Elsa ei vielä ollut valmis kertomaan kokemuksistaan:

$$
\begin{aligned}
& \text { E: Nii. Ja kyllähän me niin, ne miehet oli niin rouvia juttuja jut- } \\
& \text { telamassa siinä, mutta ei niistä auttanu välittää. } \\
& \text { EE: Nii. } \\
& \text { E: Ei niitä ollenkaa viihti puhua niitä. } \\
& \text { EE: Joo, mikäs siinä nyt, ollaanhan me nyt jo aika paljo kaikkia } \\
& \text { puhuttuki. } \\
& \text { E: Ei, ei me oikee... (H9, s. 4.) }
\end{aligned}
$$

Elsa kertoi työpaikalla nuorena naisena kokemastaan ja kuulemastaan seksuaalissävytteisestä kiusoittelusta vasta viimeisessä nauhoittamassani haastattelussa.

Haastateltavan tuttuus ja aiemmat tiedot hänen elämästään ja kertomuksistaan mahdollistivat avoimet elämäkertahaastattelut ja sen, etten suunnitellut haastattelujen kulkua etukäteen. Suurin osa tekemistäni haastatteluista alkoi jostain tietystä teemasta, joka kiinnosti minua tai nousi esiin haastattelujen ulkopuolisessa vuorovaikutuksessa. Jokainen haastattelu kuitenkin rönsyili myöhemmin toisiin teemoihin tai elämänvaiheisiin. Erityisesti haastatteluprosessin keskivaiheen haastattelut 6-8 sisälsivät pitkiä keskusteluja, joita analysoin vain vähän, vaikka monet niistä koskettivat suoraan tutkimukseni keskeisiä teemoja, esimerkiksi kokemuksia luokasta. Seuraavassa esimerkissä pohdimme Elsan kokemusta tehdastyön aloittamisesta nuorella iällä suhteessa minun edustamani sukupolven tilanteeseen:
E: Ei nykyää tehä sillä lailla. Ne käy koulun.
EE: Nii, no.
E: Ei nykyää, nii.
EE: Niin no, täytyy [ei saa selvää, puhuvat päällekkäin]. Oon- han määki tehny tuommosta työtä.
E: Niin, nii sää, nii, joka haluaa tehä.
EE: Nii, joka haluaa tehä. Pakkoha ei oo.
E: Ei. 
EE: Tai no, emmä tiiä. Kyllä mä, omalla laillaan mä katon sen kuitenkin kans pakoks.

E: Nii.

EE: Että saa rahaa.

E: Niin, no se on siinä se justii näin, mutta ku se oli niinku meikäläisen työ.

EE: Mmm. On se mullekki, kyllä määki oon puita hakannu ja pinonnu työkseni.

E: Nii, nii joo.

EE: Nii, tehny maatalon töitä ja...

E: Nii sää oot varmaa...

EE: Ja pinonnu lihakuormia kaupassa ja...

E: Niin no, se on eri, se on eri juttu jo sitte. Mutta esimerkiks, joka oli kaupassa töissä, nii sehä oli, sehä oli jalustalla.

EE: Sillo.

E: Juu.

EE: [naurahtaa] Nyt ei oo kyllä. (H7, s. 23-24.)

Keskustelumme osoittaa, miten Elsa pohtii omia kokemuksiaan ja vertaa mennyttä ja nykyistä maailmaa ja kuinka myös minä osallistun pohdintaan. Paikoin jopa haastan (tai sivuutan) Elsan näkemyksiä asettamalla oman kokemukseni hänen kokemuksensa rinnalle. Olen siis tietämättäni toteuttanut vuorovaikutuksellisen elämäkertahaastattelun mallia, enkä niinkään sellaisen elämäkerrallisen haastattelun ihannetta, jonka tarkoituksena on antaa kertojan kertoa omin sanoin elämästään ja kokemuksistaan (ks. Atkinson 1998; Hyvärinen \& Löyttyniemi 2005,192-194). En tosin voi väittää, että kyse olisi ollut tietoisesta vuorovaikutuksellisuuteen ja dialogisuuteen pyrkivästä haastatteluotteesta, vaan pikemminkin tuttuuden mahdollistamasta, haastattelutilanteen ulkopuolella olemassa olevasta läheisestä suhteestamme, johon (siihenkin) on kuulunut molemminpuolinen ajatusten vaihto ja tasavertaisuus. Tältä osin voi siis todeta, että läheinen suhteemme on tuottanut dialogista aineistoa. Kuten jo aiemmin totesin, olisin voinut huomioida aineiston dialogisen luonteen ja tutkimusasetelmaan liittyvän vuorovaikutuksen sekä molempien osapuolten aiemmat ja uudet roolit paremmin myös kertomusten analyysissä. Seuraavaksi esittelen, millaiseen lähestymistapaan päädyin analyysissäni ja pohdin, miten valitsemani käsitteet ja näkökulmat ohjasivat tekemiäni tulkintoja. 


\section{KERRONNAN DIALOGINEN ANALYYSI}

Kertomus omasta elämästä kerrotaan toiselle, kuulijalle tai lukijalle, ja hahmotetaan suhteessa toisiin ihmisiin sekä aikaan - niin menneisyyteen, nykyisyyteen kuin tulevaankin. Näistä rakentuu elämänkertomuksen dialoginen kerrostuneisuus, jonka purin tutkimuksessani seuraaviin kolmeen dialogiseen ulottuvuuteen analysoidessani Elsan kertomuksia. Ensimmäinen ulottuvuus liittyi kahdenväliseen dialogiin: haastattelumenetelmän ja asetelman ansiosta kertomukset olivat kahden eri sukupolven ja erilaisesta taustasta tulevan, vaikkakin toisilleen läheisen ihmisen välistä dialogia. Toinen ulottuvuus, yksilön dialogi itsensä kanssa, näkyi Elsan elämänkerrontaan sisältyvinä kertomuksia erilaisista ja eriaikaisista minuuksista. Kolmanneksi ulottuvuudeksi hahmotin yksilön dialogin ympäröivän maailman kanssa. Muistellessaan omaa elämäänsä ja kokemuksiaan Elsa, kuten monet muut kertojat, kävi kertomuksissaan neuvottelua omien yksilöllisten kokemustensa suhteesta kulttuurisiin arvoihin ja ideaaleihin. Lähestyin näitä dialogisuuden tasoja analyysissäni kerronnan tutkimuksesta peräisin olevien käsitteiden mikronarratiivi, avainkertomus / dialogi ja kulttuurinen ideaali / kulttuurinen (malli)kertomus kautta. Miten valitsemani käsitteet onnistuivat tavoittamaan kertomusten dialogisuuden eri ulottuvuuksia?

Jakamalla aineistoni mikronarratiiveihin ja analysoimalla niiden keskinäisiä suhteita tulin itseasiassa keskittyneeksi nimenomaan Elsan sisäiseen dialogiin. Tästä muodostui tutkimukseni pääasiallinen menetelmä, jonka seurauksena analysoin enemminkin Elsan kertomusten kautta hahmottuvaa maailmaa kuin kerrontaan liittyvää vuorovaikutusta ja yhteistä ymmärrystämme. Mikronarratiivien sisältämä dialogi suhteessa maailmaan sai myös jonkin verran sijaa, sillä taustoitin kertomuksia suhteessa Elsan elinympäristöön ja siellä vallinneeseen sosiaaliseen dynamiikkaan sekä jaettuihin arvoihin. Tätä analyyttistä tasoa, yksilön dialogia ympäröivän maailman kanssa, tarkastelin kulttuuristen ideaalien ja mallikertomuksen käsitteillä, jotka hahmotin tiettyyn kulttuuriseen kontekstiin liittyvinä hallitsevina tulkintoina ja tarjolla olevina kerronnan malleina (esim. Andrews 2002). Käsitteen kohdalla ongelmaksi tosin muodostui ideaalien ja mallikertomusten viittauksenomaisuus ja tulkinnallisuus, sillä ne vaikuttavat yksilön kertomusten taustalla ja niiden olemassaolo on kiinni nimenomaan tutkijan tulkinnasta (ks. Koskinen-Koivisto 2013, 186187 ja 2014, 51-52, 157).

Käsite avainkertomus tai sen vaihtoehtoinen versio avaindialogi on erityisen kiinnostava, sillä siihen sisältyy sekä kertojan että kuulijan tulkinta paitsi yksittäisestä kertomuksesta myös kaikesta kerrotusta, elämänkertomuksen kokonaisuudesta. Avaindialogi sisältää jonkinlaisen 
käännekohdan tai erityisen tapahtumasarjan, joka korostaa kertojan identiteettiä ja nivoo yhteen merkittäviä kokemuksia eri elämänvaiheista (ks. esim. Löyttyniemi 2004, 100). Kertoja voi palata siihen useasti kertomuksessaan tai se voi muodostua kerronnan huipentumaksi. En kuitenkaan tullut juurikaan pohtineeksi, mistä tällaisen avainkertomuksen oikeastaan tunnistaa ja kuka sen tunnistaa, enkä näin ollen käyttänyt käsitteeseen sisältyvää analyyttistä potentiaalia.

Tutkijan ja kertojan tavoitteet ovat väistämättä - tai ainakin osin erilaiset. Usein ajaudutaan tilanteeseen, jossa kertoja haluaa esittää itsensä tietyllä tavalla, ja tutkija tulkitsee toisin. Mary Erdmans $(2004,6)$ koki oman tutkimuksensa lähtökohdan ristiriitaiseksi: hänen tutkimansa sukulaisnaiset halusivat, että heidät esitetään ennen kaikkea onnellisina inmisinä, siinä missä kirjoittaja halusi esittää heidät voimakkaina ja vahvoina naisina, jotka kykenivät löytämään omanlaisensa tavan elää tyydyttävää elämää. Vaikka nämä kaksi tulkintaa eivät ole varsinaisesti ristiriidassa keskenään, niissä on kuitenkin erilainen painotus. Jälkimmäisen tulkinta on eri sukupolvea edustavan ja feministisiin teorioihin ja myös niiden kritiikkiin perehtyneen tutkijan.

Nostin tutkimusprosessini alkuvaiheessa Elsan elämänkertomuksen avaindialogiksi hänen kertomuksensa töihin palaamisesta kotiäitinä vietettyjen vuosien jälkeen. Olen analysoinut tätä kertomusta useaan otteeseen ja huomannut, että itse kertomukseen ja sitä seuraavaan polveilevaan pohdintaan sisältyy mielenkiintoisia arvioita naisen paikasta, työn merkityksestä ja toimijuudesta sekä myös erilaisia ristiriitaisuuksia. Elsa toi kokemuksensa esiin sen jälkeen, kun olin pyytänyt häntä kertomaan tehdasyhteisön muutoksesta hänen elinaikanaan kahdeksannen haastattelun alussa. Hän kertoi, kuinka perheen esikoinen ja myöhemmin myös muut lapset lähtivät opiskelemaan Vaasaan ja kuinka hänen puolisonsa ryhtyi myös opiskelemaan:

\footnotetext{
E: Mmm. Ja se, se oli sitä semmosta, että mää en sitte ois saanu ennää olla töissäkään, kun Eino valamistu. Ja minä kun oon ollu sitte aina se, mä sanon rasvanahkanen työläine, siihe aikaa sanottii, joka teki raavasta työtä. Nii mää oon kuulunu niihin. Ja sitte tuota vaari oli siellä toimihenkilöitten puolella. Että mä kärsin tästäkin.

EE: Eli oliko se sillä tavalla, että pappa ei niinku halunnu, että sä tekisit työtä?

$\mathrm{E}$ : Ei, ei ei halunnu.

EE: Että se oli vähä parempi. (H8, s. 1.)
}

Tulkitsemme Elsan kanssa yhdessä hänen aviomiehensä käytöksen johtuvan nimenomaan luokkaerosta, eikä niinkään sukupuolten välisestä työnjaosta. Elsa ottaa asian puheeksi vasta myöhemmin sen jälkeen kun on esittänyt kertomuksen työhön paluun hetkestä. Elsa kuitenkin jatkaa 
keskustelua selittämällä tilannettaan eri tavoin eri näkökulmista: vetoamalla perheen taloudelliseen ja sosiaalisen asemaan, miehen ja naisen rooleihin, muiden samassa asemassa olevien perheiden toimintaan vastaavassa tilanteessa sekä omaan ulkopuolisuuden tunteeseensa:

\begin{abstract}
E: Nii, nii ja tuota siitä oli aina puhe sitte, ku mää halusin sitte, ku pojat oli jo koulussa ja sitte tuota ne meni sitte tuota nii Vaasaan kumpiki, Simo ja Asko. Nehän oli siellä teknillise opistolla. Ne oli yhtä aikaa sitte, vaikka Asko oli jo naimisissa, että oli perhe. Taikka ei ollu perhettä, mutta vaimo. Mutta ne oli, asu siellä. Mutta Simo meni sitte taas niinku meni siihe sammaa, että sillä oli sitte semmonen soluasunto sielä. Ja tuota, no aattele nytte kun, mullaha, rahhaa tartti ja no mull'oli vaikeeta sitte yksi olla. Ja mää sitte puhun siitä, että mää meen Tuomarniemelle [tehtaan läheisyydessä sijaitseva metsäopisto] kysymään töitä. Nii se kiels sen heti jyrkästi, sinne ettet mee. Mää en puhunu kerran yhtään mitään, ku tuota sitte niin niit'oli joitain semmosia kurssia ja niitten vaimot pääs töihi. Nii mää aattelin, että kun mun mieheni kanssa lukkee, ja luki kokoajan siinä vielä. Nii määpäs meen, mää menin insinöörin työkse ja mää sanoin, esittelin itteni ja sanoin, että mää oon aatellu, että kun, ja kuullu, että semmosten vaimot pääsee töihin, joitten, miehet lukee ja taikka käyvät kurssilla. Nii, että olisko minulla mahdollisuutta. Ja hän sano het, että kyllä. Mää pääsin töihi ja ei siitä sen enempää puhuttu, ku mää rohkasin mieleni ja menin.
\end{abstract}

EE: Että itte vaan ilman lupaa.

E: Mä menin. Ilman lupaa. Nii. Mutta se oli siihe aikaa tuota nii, vaimo oli melekeen niinku mies. Miehet oli siihe aikaa mun mielestäni miehiä. Nykyaikaa verrate. Siis ne eli siihe kahtoen, mitä mies, miten mies sen määräs. Siell'oli vanhemmasta, vanhemmista ihmisistä nii mää seurasin sitäkin niin, ne oli kotona. Mies toi sen rahan mutta, jotkut hyvin harvat oli töissä. Sitte rupes, sitte rupes sen jäläkee ku muuttu se, et laajeni tehas. Sinne tuli sarana ja monia muita, et ei aina ne samat, että näin ne sano. Ja oli niinku naisille sopivaa, siis saranat ja...

EE: Nii.Teräs.

E: Nii, kaikki teräsjutut. Et siellä oli sitte hyvin paljon toimihenkilöitten vaimoja töissä. Mutta, oliha se näin, että meitä katottiin niinku vähä, että ei kaikkia juteltu meiän aikana. Mmm

EE: $M m$.

E: Että tästä mää niinkun kärsin. Että kun mää tykkäsin, että mää oon samanlainen työ-työnainen ku ne toisetkin. Emmää oo kouluja käyny. Että mulla oli vaan taito tehä sitä raskasta työtä. (H8, s. 1-2.)

Tästä avaindialogista voi tehdä sekä naisten emansipaatiota tukevan että sitä kritisoivan tulkinnan. Opiskelleelle sukupuolten väliseen tasa-arvoon pyrkivän yhteiskunnan kasvatille ensimmäinen vaihtoehto on näytti ilmeisemmältä. Toisaalta joidenkin Elsan kommenttien voi nähdä ihannoivan vanhaa patriarkaalista mallia, jossa "[m]iehet oli siihe aikaa mun 
mielestäni miehiä". Näiden lisäksi kertomuksen voi lukea myös omien rajoitettujen mahdollisuuksien tunnustamisena tai työläisidentiteetin ylistämisenä. Itse kallistuin ensin lukemaan kertomuksen emansipatorisena julistuksena, Elsan päätöksenä ottaa oma elämä omiin käsiinsä. Myöhemmin kiinnitin huomiota useisiin erilaisiin selityksiin sekä niiden ristiriitoihin sekä kertomuksen lopetukseen, joka on Elsan tulkinta ja johtopäätös tilanteestaan. Olen kuitenkin tullut ajatelleeksi, että avaindialogin tästä kertomuksesta teki nimenomaan sen monitulkintaisuus sekä oma hämmennykseni sen äärellä. Itsenäisen nuoren naisen elämää elävänä minun oli vaikea ymmärtää, että Elsa haikaili menneen turvallisen järjestyksen perään.

Elsalla niin kuin minullakin oli haastattelujen aikana erilaisia tavoitteita ja useita rooleja ja hänen roolinsa kertojana ja keskustelijana vaihtelivat eri haastatteluissa ja jopa niiden sisällä. Tunnistan Elsan asenteesta ainakin nykyelämää kritisoivan vanhemman (tai katoavan) sukupolven edustajan, humoristin, elämänohjeiden ja -asenteen jakajan sekä tasavertaisen keskustelijan roolit. Jälkimmäiset roolit tulevat esille hänen vuonna 2003 minulle kirjoittamassaan kirjeessä, jossa hän kommentoi opiskeluaikanani kirjoittamaani, hänen kertomuksiaan käsittelevää tekstiä. Elsa otsikoi kirjeensä "Mielipide Eerikan työstä". Kirjeen lopussa hän perustelee omia tutkimusprosessiin liittyviä motiivejaan seuraavasti:

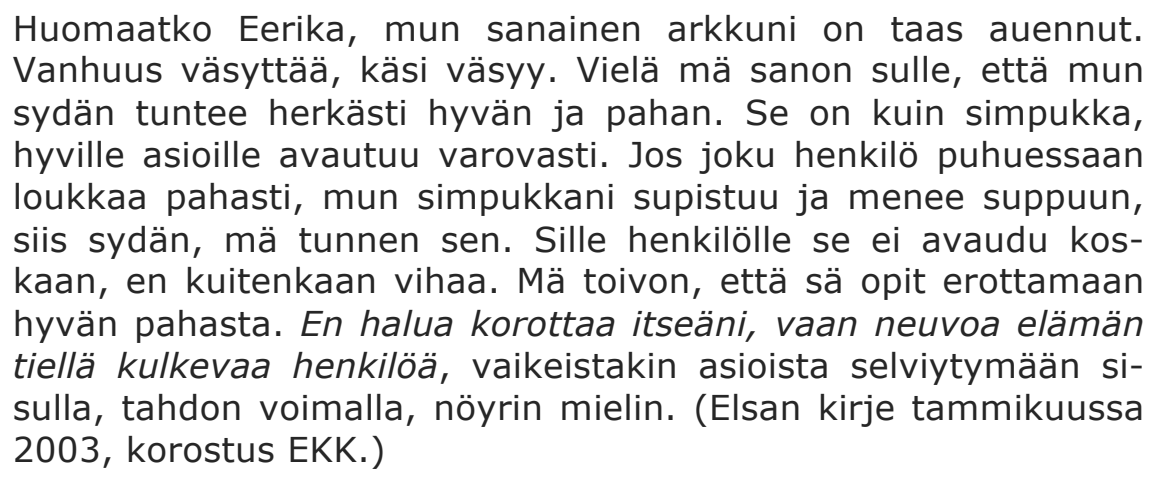

Elsa itse nostaa omasta elämästään kertomisen ja omien kokemusten jakamisen motiiviksi neuvojen ja esimerkin antamisen. Hänen tavoitteensa kertovat myös hyvin läheisestä ja tunnepitoisesta suhteestamme. Elsan kirje on yli kymmenen vuoden takaa ja ainoa palaute, jonka häneltä sain. Olenkin vuosien ajan pohtinut, mitä sanottavaa Elsalla olisi ollut myöhempiin teksteihini ja tulkintoihini. Olisiko Elsa mahdollisesti ollut joistain tulkinnoista eri mieltä? 


\section{TULKINTOJEN ETIIKKA, IHANTEET JA OIKEUTUS}

Joissakin etnografisissa tutkimuksissa, joissa sovelletaan dialogista (tai feminististä) metodologiaa, haastateltavat ovat lukeneet ja kommentoineet tutkijan tekstejä ja tutkija on ottanut näkökannat ja mielipiteet huomioon työstäessään tekstiä. Folkloristi Elaine Lawless (1992) nimittää tällaista käytäntöä vastavuoroiseksi etnografiaksi (reciprocal ethnography) ja ehdottaa, että pelkän refleksiivisyyden sijaan etnografisessa tutkimuksessa tulisi pyrkiä aitoon dialogiin nimenomaan tutkijan esittämistä tulkinnoista. Tällainen vastavuoroisuus ja dialogi toteutui esimerkiksi folkloristi Katherine Borlandin tekstissä (1991), jossa hän hyödynsi isoäitinsä kriittisiä kommentteja ja arvioi omia tulkintojaan liittyen isoäitinsä kertomuksiin elämästään. Myös sukulaisnaisiaan tutkineen Mary Erdmansin (2004) tutkimuksessa hänen tutkimansa perheenjäsenet kommentoivat hänen tekstiään ja saivat ehdottaa, mitä haluavat siitä poistettavan.

Itse olisin toivonut, että olisin saanut mahdollisuuden kuulla, mitä mieltä Elsa oli tulkinnoistani. Näin ei kuitenkaan käynyt, sillä hän ei voinut kommentoida tutkimustekstejäni kahdesta syystä. Toinen liittyy tutkimuksen alkuvaiheessa laatimaamme suulliseen sopimukseen siitä, että kirjoittaisin väitöskirjani englanniksi eli hänelle vieraalla kielellä. Tämä ratkaisu oli helpotus Elsalle, joka toivoi, ettei tutkimus hänen elämästään päätyisi naapureiden juoruilun kohteeksi. Kielen valinnalla oli kuitenkin ennalta arvaamattoman suuri vaikutus tulkintoihin ja koko tutkimusprosessiin. Se nimittäin etäännytti minut tehokkaasti aineistosta ja suhteestani Elsaan, jopa liiaksi. Joka tapauksessa tiesin alusta lähtien, ettei Elsa voisi lukea tuottamaani tekstiä. Uskoin kuitenkin, että voisimme käydä keskusteluja ja että voisin tarvittaessa täydentää aineistoani. Elsa kuitenkin joutui vuonna 2008 sairaalaan ja toistuviin lonkkaleikkauksiin, minkä jälkeen hänen muistinsa ei enää toiminut normaalisti. Jo tuolloin tein päätöksen olla enää haastattelematta Elsaa, mikä osoittautui hyväksi ratkaisuksi, sillä etenkin hänen lähimuistinsa heikkeni nopeasti, ja vuonna 2010 hän sai Alzheimer-diagnoosin. Tutkimukseni valmistuttua muistisairaus oli pyyhkinyt Elsan mielestä koko tutkimukseni. Seurauksena Elsan sairastumisesta pohdin, oliko tutkimukseni lainkaan eettisesti kestävää. Päädyin kuitenkin jatkamaan sitä samalta pohjalta, mutta jätin työn ulkopuolelle myöhemmät huomioni Elsan kerronnan muuttumisesta muistisairauden myötä. Niiden käyttämiseen en olisi enää voinut tiedustella tutkimuslupaa häneltä itseltään.

Koko tutkimusprosessini ajan olin myös pohtinut, missä määrin minun tulisi kertoa tutkimuksestani sukulaisilleni, etenkin niin sanotulle välisukupolvelle eli isälleni ja hänen sisaruksilleen. Mietin myös, tulisiko heidänkin 
näkemyksensä Elsan elämästä ja perheemme historiasta ottaa jotenkin huomioon tutkimustekstissä. Oman kotiseutunsa poroelinkeinoa tutkinut Helena Ruotsala $(1998,109)$ on todennut tuttuuden ja sisäpiiriläisyyden lisäävän erilaisia odotuksia tutkijaa ja hänen tuottamaansa lopputulosta kohtaan. Myös Riina Haanpää (2005) on pohtinut eri perheenjäsenten näkökulmien yhteensovittamista omassa tutkimuksessaan. Viitaten muistitiedon luonteeseen kunkin kertojan omana totuutena ja tulkintana hän muistuttaa, että myös oman suvun tutkijalla on halu muodostaa oma näkemys suvun menneisyydestä ja että tuo näkemys saattaa olla ristiriidassa joidenkin suvun jäsenten kanssa. Mutta mitä odotuksia minua (tai Elsaa) kohtaan oikeastaan oli? Olivatko jotkut käsittelemistäni aiheista sellaisia, joita sukulaiseni eivät olisi halunneet hänen tai minun käsittelevän? Uskoin ja luotin siihen, että sukulaiset hyväksyisivät suurimman osa väitöskirjani teemoista. Esimerkiksi kokemus sosiaalisesta noususta ja sen aiheuttamista ristiriitaisista tunteista on tuttu isäni, tätini ja setäni sukupolvelle. Vaikkeivat he itse olisi ottaneet aktiivista roolia asian suhteen kertomalla siitä minulle tai suuremmalle yleisölle, uskon, että aiheen käsittely ylipäätään on tarpeellista myös heidän mielestään. Elsan sairastumiseen ja muistisairauden etenemiseen liittyi kuitenkin monia vaikeita tunteita, jotka ovat väistämättä vaikuttaneet tutkimusprosessiin ja tulkintoihini. Aiempi dialoginen ja melko tasa-arvoiseksi kokemamme suhde muuttui toisenlaiseksi, lähemmäs hoivasuhdetta, mikä on saanut minut suhtautumaan Elsaan suojelevammin. Samalla kun olen analysoinut hänen kertomuksiaan, olen myös käynyt läpi surua ja luopumisen prosessia, sillä suuri osa hänen persoonastaan on muuttunut ja kadonnut tutkimusprosessin aikana. Suojeleva asenteeni on liittynyt paitsi Elsan asemaan omassa yhteisössään ja naapurustossaan, myös Elsan ja hänen läheistensä suhteeseen, sillä etenkin muistisairauden puhkeamisen aikaan perheessä oli erilaisia jännitteitä.

Käsittelin edellä Elsan elämän avainkertomukseen liittyviä tulkinnan mahdollisuuksia ja omaa hämmennystäni, joka nousi paitsi itse haastattelutilanteessa kerrotusta ja jaetuista myös tutkimuksen ulkopuolella kuulemani ja kokemani vaikutuksesta. Vaikka kirjoitin auki kertomuksen eri suuntiin kurottavat tulkinnat ja keskenään ristiriitaiset kokemukset, päädyin kuitenkin korostamaan tutkimuksessani Elsan minulle itsestään kertomaa identiteettiä työläisenä. Tämä identiteetti korostui vuorovaikutuksessa minun kanssani, mahdollisesti siksi, että Elsa reflektoi omaa elämäänsä suhteessa minun elämääni nykyaikana. Reflektoidessani tutkimusprosessia jälkikäteen olen kuitenkin tullut ajatelleeksi, ettei vastakkaisuus noussut ainoastaan Elsan asemoitumisesta suhteessa minuun, vaan myös minun suhteestani nykyiseen, vanhaan ja hauraaseen Elsaan, jonka kertomusta elämästään minä konstruoin. Ehkä minä halusin nähdä hänet vahvana ja ylpeänä omasta itsestään. Vaikka tiedostin 
jollakin asteella nämä tulkintojeni taustalla vaikuttavat moninaiset tunteet ja tekijät, en kirjoittanut niitä auki tutkimuksessa. Kyseessä oli valinta, joka kumpusi tarpeestani ottaa etäisyyttä itseäni lähellä olevaan tutkimuskohteeseen. Tämän etnografiseen tutkimukseen olennaisesti kuuluvan liikkeen purkaminen on ollut haastavin osa tutkimusprosessiani.

\section{LÄHELTÄ ETÄÄLLE JA LIIANKIN KAUAS - ETÄÄNTYMINEN OSANA TUTKIMUS- TA JA KIRJOITUSPROSESSIA}

Suurimman sisäpiiriläisyyteen liittyvän haasteen katsotaan liittyvän tutkimuskohteen läheisyydestä aiheutuvaan sokeuteen. Omaa sukua ja perhettä tutkiva on kasvanut tutkittavaan kulttuuriympäristöön, sen arkisiin tapoihin ja julkilausumattomiin käytäntöihin, minkä takia se voi näyttäytyä monilta osin itsestään selvänä ja mutkattomana. Sukulaisuussuhteen vaikutuksen ja tutkijan päällekkäisten roolien arvioimisen ajatellaan niin ikään olevan hankalaa (ks. Vuorinen 2002; Haanpää 2005). Oman sukunsa muistitietoa tutkineen folkloristin Riina Haanpään mukaan (2005, 2-3) huomiot sukulaisuuden vaikutuksesta tutkimukseen ovat liittyneet nimenomaan kentällä olon ja aineistonkeruutilanteiden käytäntöihin. Vähemmälle sen sijaan on jäänyt omaa kulttuuriaan ja sukuaan tarkastelevan tutkijan kriittisen otteen analysointi tai se, millä tavalla tutkija on tietoinen tarkastelemastaan asiasta. Tulkitsen Haanpään viittaavan tarpeeseen arvioida kriittisen tulkinnan mahdollisuuksia ja omaa lähipiiriään tutkivan piileviä asenteita ja sitoumuksia.

Lähellä olemiseen, mutta samalla tutkimuksen teolle olennaisen etäisen ja kriittisen katseen saavuttamiseen sisältyy haasteita, jotka liittyvät ennen kaikkea tutkijan kykyyn havainnoida ja analysoida itseään ja omaa toimintaansa sekä läheisyyteen ja etäisyyteen liittyvää liikettä, joka on etnografisen tutkimuksen olennainen voima. Tulkintojen muuttuminen, ristiriitaisuus ja niiden kytkökset tutkijan kokemuksiin, tunteisiin ja minuuteen ovat välttämätön osa etnografista tutkimusprosessia, mutta eivät suinkaan helppoja hahmottaa ja kirjoittaa auki. Antropologi Amanda Coffeyn (1999) mukaan etnografiseen tutkimusprosessiin liittyy aina identiteettityötä, jonka kautta tutkija paitsi solmii tunnepitoisia suhteita ja oppii uutta, myös kasvaa ihmisenä. Coffeyn mukaan tutkijan ei ole välttämätöntä kirjoittaa itseään mukaan tutkimustekstiin, mutta sen sijaan on välttämätöntä tiedostaa, että tutkimus vaikuttaa myös tutkijaan itseensä ja hänen näkemyksiinsä maailmasta.

Esimerkiksi Mary Erdmans (2004) kirjoitti tutkimuksen loppuun kappaleen, jossa kävi läpi omia kokemuksiaan, perhetaustaansa ja sen vaikutusta omaan ajatteluunsa. Minä en sisällyttänyt väitöskirjaani osiota, jossa olisin pohtinut omia kokemuksiani ja tutkimusprosessin vaikutusta omaan 
itseeni, käsityksiini perheestäni, luokka-asemasta tai suomalaisesta yhteiskunnasta. Jätin siis tietoisesti itseni ja oman identiteettityöni tutkimukseni ulkopuolelle. Tämä päätös liittyi ajatukseen siitä, että halusin keskittyä Elsaan ja hänen kertomuksiinsa enkä itseeni. Itsestä kirjoittamisen välttämiseen vaikutti myös kirjoittaminen vieraalla kielellä. Vaikka olen tottunut kirjoittamaan tutkimustekstejä englanniksi, omien kokemusten prosessointi vieraalla kielellä tuntui vaikealta tai lähes mahdottomalta. Tämä ja aiemmin käsittelemäni käsitteelliset valintani ja näkökulmani jättivät kokonaisuudessaan minut itseni lähestulkoon pois analyysistäni.

Paikantuneen tiedon kriteerejä ja edellytyksiä pohtineet kulttuurintutkijat muistuttavat, ettei pelkkä tunnustuksellinen itsereflektio kuitenkaan tee analyysistä refleksiivistä (esim. Fingerroos 2003; Ojanen 2008). Refleksiivisyys vaatii analyyttistä etäisyyttä, joka syntyy esimerkiksi käsitteiden avaamasta laajemmasta perspektiivistä. Karoliina Ojasen mukaan etääntyminen merkitsee uudelleentulkintojen mahdollisuutta (Ojanen 2008, 11). Tutkimusprosessin ja sen eri vaiheiden myötä tutkija siis näkee paitsi tutkimansa aineiston myös siihen liittyvät omat tulkintansa toisin ja uudesta näkökulmasta. Etnografisen tutkimuksen onkin sanottu perustuvan läheisyyden ja etääntymisen sekä osallisuuden ja vierauden väliselle dialektiikalle. Tutun ja vieraan, erilaisten roolien ja perspektiivien vuorottelu nähdään välttämättömänä osana etnografista tutkimusprosessia. (Ks. esim. Coffey 1999). Etääntyminen ei kuitenkaan tässä tarkoita objektiivisuutta, joka edelleen on julkilausuttuna tavoitteena joissakin etnografisissa tutkimuksissa, jopa niissä, joissa sisäpiiriläisyys on tutkimuksen lähtökohta (esim. Mantsinen 2014). Sen sijaan etääntymisen voi nähdä erilaisten roolien ja näkökulmien tiedostamisena, mikä mahdollistuu usein ajallisen etäisyyden ja erilaiseen ympäristöön siirtymisen myötä.

Itselleni oli tärkeää katsella suomalaiseen yhteiskuntaan kiinnittyvien arvojen ja normien läpäisemiä kertomuksia toisesta kulttuurisesta viitekehyksestä käsin. Vieraillessani Yhdysvalloissa vuosina 2009-2010 tutustuin paikallisten folkloristien teksteihin, jotka käsittelivät Appalakkien alueella asuvien valkoisten työväenluokkaisten ihmisten elämää (ks. esim. Stewart 1996; Sawin 2004). Lukemani tekstit ja keskustelut paikallisten tutkijoiden kanssa asettivat uuteen valoon omat käsitykseni esimerkiksi työn eetoksesta ja työläisidentiteetistä, jotka amerikkalaisessa kontekstissa rakentuvat suomalaisista poikkeavien historiallisten prosessien sekä arvojen ja politiikan risteyksissä. Esimerkiksi yksilöllisen taloudellisen menestyksen merkitys hyvän työntekijän identiteetille on Suomessa vähäisempi kuin Amerikassa. Tärkeää sen sijaan on oman osan tekeminen ja työ itsessään - arvot, jotka olivat merkityksellisiä myös Elsan kerronnassa. Tämä oivallus auttoi minua purkamaan muun muassa 
avainkertomukseksi tunnistamaani kertomusta työhön paluusta ja Elsan kokemuksia muutoksesta sekä omasta paikastaan maailmassa. Samalla tulin myös pohtineeksi, miksi työ sai niin suuren roolin kertomuksessa, jonka yleisönä minä ja muu akateeminen maailma olemme, ja kuinka luokka-asemaan liittyvät muutosprosessit ovat edelleen käynnissä, ja millaisia dramaattisia kehityskulkuja ja sukupolvien välisiä kuiluja ja niihin sisältyy.

Kirjoittamiseen liittyvät valintani, kuten kirjoittaminen vieraalla kielellä sekä henkilökohtaisuuden ja tunnustuksellisuuden välttäminen, edistivät etääntymistäni tutkimuskohteestani ja aineistostani jopa liiaksi saakka. Toisaalta tietynlainen etääntyminen on aina tarpeen, jotta aineiston voi nähdä uudessa ja laajemmassa tieteellisessä ja teoreettisessa valossa.

\section{LOPUKSI}

Olen edellä pohtinut, millaista tietoa dialoginen ja refleksiivinen tutkimusote tuottavat ja millaisia välineitä ne edellyttävät käymällä läpi tutkimusprosessiin liittyviä vaiheita ja valintojani. Dialoginen ontologia johtaa tarkastelemaan tiedon rakentumista kahden ihmisen ja erilaisten maailmojen välillä. Se siis kannustaa tutkijan ja tutkittavan välisten erojen tarkasteluun, minkä olen jälkikäteen nähnyt ohjanneen oman väitöskirjani tutkimuskohteen ja -aineistoni muodostumista ja valintaa. Dialogisuuden funktionaalisuus puolestaan tulee esiin elämänkerrontaan sisältyvän sekä aineiston dialogisten kerrosten myötä. Olen kiinnittänyt huomiota väitöstutkimuksessani tekemiini metodologisiin valintoihin, joihin kuului olennaisesti keskittyminen Elsan elämänkertomukseen sisältyvän, yksilön kokemusten ja laajemmin jaettujen kulttuurisen kertomusten väliseen dialogiin. Haastatteluissa ja dialogisessa elämänkerronnassa oli kuitenkin nähtävissä useita muita kerroksia, kuten ristiriitoja tutkijan ja tutkittavan ymmärrysten välillä sekä kertojan ja / tai tutkijan eriaikaisten näkemysten ja pohdintojen välillä. Dialogisen kerrostuneisuuden laajempi purkaminen olisikin ollut väitöstutkimuksessani paikallaan.

Dialogisuuden eettinen ulottuvuus on läsnä kaikessa kulttuurintutkimuksessa. Läheistä ihmistä tutkittaessa vuorovaikutuksen refleksiivinen ja kriittinen analyysi sekä koko tutkimusprosessin refleksiivinen arvioiminen on hankalaa, mutta erityisen tarpeellista. Valitsemalla tutkimuskohteekseen läheisen ihmisen tutkija tuo tutkimuksen kontekstiin myös tutkimusta edeltävän suhteen sekä siihen liittyvät aiemmat tiedot ja tunteet. Tähän liittyy näkökohtia, jotka eivät välttämättä aina johda eettisesti kestävään ja läpinäkyvään tutkimukseen. Tutkija joutuukin tasapainoilemaan kahden roolin sekä maailman ja niistä käsin häneen kohdistuvien, 
joskus keskenään varsin erilaisten vaatimusten välillä. Eettisten kysymysten ratkaisuun vaikuttaa olennaisesti, että läheisen ihmisen ja erityisesti sukulaisen kohdalla tutkimuksen ulkopuolinen suhde tutkimuksen kohteeseen jatkuu (ks. myös Ruotsala 1998). Tutkimusprosessin myötä suhde läheiseen ihmiseen ja ymmärrys hänen elämästään kuitenkin muuttuu. Tämän muutoksen ja tutkijan tekemien, osin intuitiivistenkin valintojen hahmottaminen voi olla mahdollista vasta varsinaisen tutkimusprosessin jälkeen. Minun ja Elsan välistä suhdetta ovat viime vuosina määrittäneet paitsi tutkimusprosessini myös Elsan muistisairaus ja sitä seurannut haurastuminen ja riippuvaisuus toisista ihmisistä. Tämä ohjasi minut suojelemaan Elsaa tutkimuskohteena enemmän kuin olisi ehkä ollut tarpeen.

Etnografisessa tutkimuksessa etäisyys ja läheisyys eivät ole yksinkertaisia prosesseja, vaan ne ovat jatkuvassa liikkeessä. Erilaiset positiot tuottavat erilaista tietoa, vuorovaikutusta ja tulkintoja. Haastattelutilanteessa läheistä ihmistä tutkivalla on jonkinlainen etulyöntiasema taustatietojen sekä tutkijan ja tutkittavan välisen luottamuksen syntymisen suhteen. Kun mukana on tutkimuksellinen konteksti ja eräänlainen kolmas taho, esimerkiksi nauhuri, joka symboloi myös tutkimuksen muita yleisöjä, toisilleen tuttujen läheistenkään inmisten vuorovaikutus ei välttämättä kuitenkaan aina ole erityisen luontevaa, ainakaan aluksi. Itse en antanut Elsalle ja hänen ajatuksilleen tarpeeksi tilaa ensimmäisissä haastatteluissa, vaan keskeytin hänet kysymyksilläni esittäen samalla asiantuntijaa ja kenttänsä hallitsevaa tutkijaa. Toisaalta osallistuin läpi tutkimusprosessin keskusteluun omana itsenäni ja uskalsin paikoin jopa haastaa Elsan näkemyksiä samaan tapaan kuin muissa tutkimusprosessin ulkopuolisissa keskusteluissa. Vaikka Elsa kertoi minulle monista elämänsä osa-alueista, jäi meiltä käsittelemättä välistämme suhdetta koskettavat teemat kuten vanhemmuus ja isovanhemmuus sekä lähimmät, perheemme sisäiset ihmissuhteet. Näin ollen tutkimusaineistostani puuttuu osa Elsan tuttua ja arkipäiväistä elämää, joka olisi todennäköisesti tullut käsitellyksi jonkun toisen keskustelukumppanin kanssa.

Dialogisen tutkimusotteen nähdään usein kulkevan käsi kädessä refleksiivisyyden kanssa, mitä pidetäänkin edellytyksenä etnografisen tutkimuksen tutkimuskohteen, tutkijan ja tutkittavan välisen ymmärryksen tavoittamiselle (ks. esim. Sawin 2004; Ojanen 2008, 10). Refleksiivisyys edellyttää, että myös tutkija käy dialogia itsensä kanssa. Yhtenä refleksiivisyyden välineenä toimii etääntyminen, jonka voi hahmottaa uusien näkökulmien syntymisenä ja johon tarvitaankin usein tutkijan ulkopuolisia yllykkeitä, vieraita ympäristöjä ja konteksteja. Toisaalta pelkästään kirjoittamisen prosessi ja siihen liittyvät valinnat etäännyttävät tutkijan tarkastelemastaan aineistosta, jopa liiaksi, kuten itse katson omalla 
kohdallani tapahtuneen. Tämän artikkelin kirjoittaminen puolestaan on ollut eräänlainen (uudelleen)lähentymisen prosessi, jossa olen tarkastellut tuottamaani tietoa ja prosessoinut myös omia tutkimusprosessiin liittyviä tunteitani, mikä on toivoakseni lisännyt tutkimukseeni refleksiivisen ja dialogisen kerroksen, joka siitä jäi alun perin puuttumaan.

\section{LÄHTEET}

\section{Tutkimusaineistot:}

Elsa Koskisen kommentti kirjoittajan maisteriseminaariesitelmään tammikuussa 2003.

Elsa Koskisen haastattelut:

H1 25.1.2001 (105 min) tehdasyhteisön suullinen perinne, työ, lapsuus

H2 ?.3.2001 (30 min) ruoka, työ, työkaverit

H3 26.6.2001 (45 min) kaupat ja sota-aika

H4 8.9.2001 (60min) työ (piikominen, tehdastyö), sota-aika

H5 9.12.2001 (60min) elämänkertomus, elämänvaiheet, työ ja vapaaaika

H6 19.12.2001 (60min) nuoruus, vapaa-aika, yliluonnollinen

H7 1.1.2002 (60 min) paikallinen murre, lapsuus, luokka

H8 6.1.2002 (60min) muutos, eläkkeelle jääminen, kalastus, matkustaminen

H9 16.2.2002 (60min) unet, yliluonnollinen, perhe, huumori

H10 24.5.2002 (60 min) perhe, nuoruus, vapaa-aika, vanhuus

H11 28.9.2002 (60 min) sanonnat, perhe, sota-aika, vaatteet

H12 ?.6. 2004 (50 min) työ, sukupuolten väliset suhteet, vitsailu, nuoruus ja vapaa-aika

Haastattelunnauhat ovat tekijän hallussa. 
KIRJALLISUUS

Alver, Bente Gullveig 1990: Creating the Source through Folkloristic Fieldwork. A Personal Narrative. Helsinki: Academia Scientiarum Fennica.

Andrews, Molly 2002: Counter-narratives and the Power to Oppose. Narrative Inquiry 12(1), 1-6.

Aro, Laura 1996: Minä kylässä. Identiteettikertomus haastattelututkimuksen folklorena. Helsinki: SKS.

Arvidsson, Alf 1999: Folklorens former. Lund: Studentlitteratur.

Atkinson, Robert 1998: The Life Story Interview. Thousand Oaks, London, New Delhi: Sage Publications.

Bakhtin, Mihail 1981: The Dialogic Imagination: Four Essays. Austin and London: University of Texas Press.

Borland, Katherine 1991: "That's Not What I said". Interpretive Conflict in Oral Narrative Research. - Berger Cluck, Sherna \& Patai, Daphne (eds.), Women's Words. The Feminist Practice of Oral History. London \& New York: Routledge. 63-75.

Collins, Peter \& Gallinat, Anselma 2010: The Ethnographic Self as Resource. An Introduction. - Collins, Peter \& Gallinat, Anselma (eds.), The Ethnographic Self as Resource. Writing Memory and Experience into Ethnography. New York \& Oxford: Berghahn Books. $1-22$.

Coffey Amanda 1999: The Ethnographic Self. Fieldwork and the Representation of Identity. London: Sage.

Crapanzano, Vincent 1990: On Dialogue. - Tullio Maranhão (ed.), The Interpretation of Dialogue. Chicago: The University of Chicago Press. 269-291.

Davies, Charlotta Aull 2002: Reflexive Ethnography: A Guide to Researching Selves and Others. London: Routledge.

Fingerroos, Outi 2003: Refleksiivinen paikantaminen kulttuurien tutkimuksessa. - Elore 10(2) [online].

<http://www.elore.fi/arkisto/2_03/fin203c.html> [11.8.2014.]

Erdmans, Mary Patrice 2004: The Grasinski Girls: The Choices They Had and the Choices They Made. Athens: Ohio University Press.

Haanpää, Riina 2005: Velisurmasta suvun muistoksi. - Elore 12(1) [online]. <http://www.elore.fi/arkisto/1_05/haa1_05.pdf > . [11.8.2014.] 
Hyvärinen, Matti \& Löyttyniemi, Varpu 2005: Kerronnallinen haastattelu. - Ruusuvuori, Johanna \& Tiittula, Liisa (toim.), Haastattelu : tutkimus, tilanteet ja vuorovaikutus. Tampere: Vastapaino. 189222.

Klein, Barbro 2006: An Afternoon Conversation at Elsa's. - KaivolaBregenhøj, Annikki \& Klein, Barbro \& Palmenfelt, Ulf (eds.), Narrating, Doing, Experiencing. Nordic Folkloristic Perspectives. Helsinki: SKS. 79-100.

Koskinen-Koivisto, Eerika 2013: A Greasy-Skinned Worker - Gender, Class and Work in the 20th-Century Life Story of a Female Labourer [online]. Jyväskylä: University of Jyväskylä.

<http://urn.fi/URN:ISBN:978-951-39-5517-5> [6.8.2014.]

Koskinen-Koivisto, Eerika 2014: Her Own Worth - Negotiations of Subjectivity in the Life Narrative of a Female Labourer. Helsinki: Finnish Literature Society.

Lawless, Elaine 1992: "I was afraid someone like you...an outsider... would misunderstand" Negotiating interpretive differences between ethnographers and subjects. - Journal of American Folklore 105(417): 302-314.

Liljeström, Marianne 2004: Feministinen metodologia - mitä se on? Liljeström, Marianne (toim.), Feministinen tietäminen. Keskustelua metodologiasta. Tampere: Vastapaino. 9-21.

Löyttyniemi, Varpu 2004: Kerrottu identiteetti, neuvoteltu sukupuoli. Auscultatio medici. Jyväskylä: Minerva.

Mannheim Bruce \& Tedlock, Dennis 1995: Introduction. - Tedlock, Dennis \& Mannheim Bruce (eds.), The Dialogic Emergence of Cultures. Urbana \& Chicago: University of Chicago Press. 1-32.

Mantsinen, Teemu T. 2014: Helluntailaiset luokkakuvassa. Uskontokulttuuri ja yksilön luokka-asema Turun Helluntaiseurakunnassa. Turku: Turun yliopisto [online]. <https://www.doria.fi/bitstream/handle/10024/98814/Annales_C38 7.pdf? sequence $=2>$ [4.9.2014.]

Marander-Eklund, Lena 2011: Livet som hemmafru. - MaranderEklund, Lena \& Östman, Ann-Catrin (red), Biografiska betydelser. Norm och Erfarenhet i levnadsberättelser Möklinta: Gidlunds förlag. 133-156.

Marcus, George E. \& Fischer, Michael M.J. 1986: Anthropology as Cultural Critique: An Experimental Moment in the Human Sciences. Chicago \& London: The University of Chicago Press. 
Ojanen, Karoliina 2008: Kenttäkokemuksesta tiedoksi. - Elore 15(1) [online]. <http://www.elore.fi/arkisto/1_08/oja1_08.pdf> [11.8.2014.]

Ruotsala, Helena 1998: Mie kotona kentällä ja kentällä kotona. Mäkikalli, Maija \& Oinonen, Paavo (toim.). Integraatio, identiteetti, etnisyys. Tarkastelukulmia kulttuuriseen vuorovaikutukseen. Turun yliopisto: Turku. 88-117.

Sawin, Patricia 2004: Listening for a Life. A Dialogic Ethnography of Bessie Eldreth through Her Songs and Stories. Logan: Utah State University Press.

Scheiberg, Susan L. 1990: A Folklorist in the Family: On the Process of Fieldwork among Intimates. - Western Folklore 49: 208-214.

Siikala, Anna-Leena 1984: Tarina ja tulkinta: tutkimus kansankertojista. Helsinki: SKS.

Steedman, Carolyn K. 1994 [1986]: Landscape for a Good Woman. The Story of Two Lives. New Brunswick \& New Jersey: Rutgers University Press.

Stewart, Kathleen 1996: A Space on the Side of the Road: Cultural Poetics in an "Other" America. Princeton: Princeton University Press.

Sykäri, Venla 2012: Dialogic Methodology and the Dialogic Space Created after an Interview. - RMN newsletter 4: 80-88. [online]. $<$ http://www.helsinki.fi/folkloristiikka/English/RMN/RMNNewsletter_ 4_MAY_2012_Approaching_Methodology.pdf> [9.9.2014.]

Ukkonen, Taina 2000: Menneisyyden tulkinta kertomalla. Muistelupuhe oman historian ja kokemuskertomusten tuottamisprosessina. Helsinki: SKS.

Vasenkari, Maria 1996: Mitä se sanoo? Mistä se kertoo? Dialoginen näkökulma kenttätutkimusaineiston tuottamiseen. - Hovi, Tuija \& Tarkka, Lotte (toim.), Uskontotiede - Folkloristiikka. Kirjoituksia opinnäytteistä. Etiäinen 3: 84-109.

Vasenkari, Maria \& Pekkala, Armi 2000: Dialogic methodology. - Lauri Honko (ed.), Thick Corpus, Organic Variation and Textuality in Oral Tradition. Helsinki: Finnish Literature Society. 243-254.

Vuorinen, Pihla 2002: Doing research among family and friends. Problems and advantages. - Jaago, Tiiu, Kõiva Mare \& Kärsna, K. (eds.), Lives, Histories and Identities. Studies on Oral History, Lifeand Family Stories. Tartu: University of Tartu; Estonian Literary Museum. 348-363. 


\section{Wilson, William A. 1991: Personal Narratives: the Family Novel. -} Western Folklore 59(2): 127-149.

Filosofian tohtori Eerika Koskinen-Koivisto työskentelee tutkijatohtorina Helsingin yliopistossa ja vierailee parhaillaan Wisconsinin yliopistossa Madisonissa. Artikkeli on osa kirjoittajan väitöskirjan jälkeistä tutkimusta Suomen Akatemian hankkeessa Happy Days? The Everyday Life and Nostalgia in The Extended 1950s (SA 137923). 